\title{
Public Perception of Disaster Landslides and Efforts to Overcome in Subdistrict Kaloran Central Java Indonesia
}

\author{
Erni Suharini", Dewi Liesnoor S, Edi Kurniawan \\ Semarang State University, Indonesia \\ *Corresponding Author: ernisuharini@gmail.com
}

Copyright (C) 2014 Horizon Research Publishing All rights reserved.

\begin{abstract}
The purpose of this study is to determine the public perception about a landslide in the Kaloran sub district Waterford District Central Java Indonesia. The population in this study is the people who have experienced landslides disaster. The variables of study include public perception of landslides, landslide disaster management by the community, and landslide disaster management by the government (BPBD, sub districts, villages). Data collection techniques use tests, questionnaires, interviews, and observations. The analysis uses descriptive analysis and triangulation analysis to test the validity of the data. The results showed the public perception of the landslide (aspects of cognition) classified as less of ( $56.76 \%$ ), Public perception of landslides (affective aspect) classified as good of (40.54\%). Public perception of landslides (aspect of conation) classified as good of ( $45.95 \%$ ). Landslide disaster management efforts by the government in terms of utilization of early warning and prevention efforts require funding. Landslide disaster management efforts by local governments (BPBD) are less in terms of hazard warning signs, monitoring the implementation of regulations on spatial planning, building permits, relocation of residents who are in landslide-prone areas, satisfaction of basic needs and education of disaster. Suggestions should be directed to the community to participate in disaster landslide management efforts.
\end{abstract}

Keywords Perception, Disaster, Landslide

\section{Introduction}

Temanggung District is a district that has several areas prone to landslides. One of sub district that has a high level of vulnerability to landslides is Kaloran sub district, especially Kalimanggis Village, Getas Village, and Tleter Village. It was Recorded over the last five years of 13 landslides occurred in the village of Kalimanggis, 9 times landslide in the village of Getas, and 7 times the landslide in the village of Tleter ( Temanggung Government, 2009). The phenomenon of landslides in the Kaloran sub District especially in the three villages experienced almost every years, the Kalimanggis Village, Getas Village, and Tleter Village provide an understanding of its own to society. By seeing and hearing the disaster phenomenon will shape the public perception of the disaster itself.

Perception as a process which is preceded by the sensing process, is a process receives a stimulus by individuals through sensory organs (Walgito, 2003:87-88). There are three aspects, namely perception of Cognition, Affection / Emotions, Conation. Aspects of cognition includes the knowledge component, affective aspects related to the feelings and evaluation components, and conation aspects concerning to motivation, attitude, behavior or activities of individuals according to their perceptions upon a particular object or situation.

According to IDEP Foundation there are the main matter about landslides which are: definition of the landslide, landslide causes, common symptoms, impact, preparedness action, actions in the event of landslides, and action after landslide.

Disaster risk reduction in Indonesia prioritizes the important aspects that need to be executed immediately. National Action Plan for Disaster Risk Reduction (NAP DRR) established as a commitment of the Government of Indonesia to the UN Resolution NO.63/1999 followed up with the Hyogo Framework for Action and the Beijing Action. Disaster risk reduction in Indonesia is conducted by considering sustainability and participation of all parties (Wuryanti, 2007; Astuti and Sudaryono, 2010).

One of the priorities of the Hyogo Framework for Action is the importance of using knowledge, innovation, and education to build a culture of safety and resilience at all levels (in the long term is expected to be able to build disaster preparedness for effective response at all levels). This is in accordance with the frame of mind developed in disaster risk reduction or mitigation, include four framework are: 1) Awareness (behavioral change) ; 2) Knowledge Development (one of them are Education and Training) ; 3) Public Commitment ; 4) Risk Assessment.

The second concept is Knowledge Development as the main target of studies and training. One of the priorities for $\mathrm{PRB}$ action is the importance of knowledge, innovation, 
education for building safety and resilience at all levels. From this many disaster mitigation activities, one of the most strategic is learning or education to the community. Education is an effective means to shape people's behavior in facing the disaster (Yaniv, 2010).

Based on the observations made in the Kaloran sub District, if found that landslides often occur in the area, especially in the Kalimanggis, Getas and Tleter village. Various attempts have been made to increase public awareness of landslide disaster, but the fact is not shown significant results.

Based on geological location, Indonesia is in convergent area, which is located in the area between the 3 meeting of the world big plates, namely the Indo-Australian plate, the Pacific plate and the Eurasian plate which is an area that is prone to seismic activity. Active mountain ranges that encircle almost the entire territory of Indonesia have made the region prone volcanism. Natural factors convergen area has the characteristics of active mountain path with the specific climatic conditions that is a high rainfall. Indonesia is geographically located in an area of low latitude which is a tropical region, with the characteristics of high rainfall and a long dry season. But the phenomenon of global warming is a natural phenomenon caused by the influence of the greenhouse effect, causing tremendous climate change so that people are no longer able to predict when the rains come and when it ends. Real impact is experienced by people of Temanggung is tobacco crops failure.

Natural conditions of Temanggung region generally is depressed areas, which is low area in the middle, while the shape of the surrounding is mount, hills, or mountains. The geology is composed of igneous, which is sedimentary rock of volcanic pyroclastic Sindoro-Sumbing and surrounding areas. Morphological conditions divided into two plains and highlands. Low land formed by sediments or alluvial, while highland formed by undulating hills that situation is surging. This condition allows for landslide vulnerability.

Based on the data obtained from the site of Temanggung local government, there have been landslides in several places such as in Kaloran Sub district (Kalimanggis, Getas, Nglamuk, and Kemiri Village), Gemawang Sub district (Blawong wetan Village), Candiroto Sub district (Gunung Payung Village) Bejen Sub district (Ngalian Village), Kledung Sub district (Kalianggro Village), and the Sub district of Ngadirejo (Gedegan Village). Other potential areas of landslides are Tembarak, Selopampang, Tretep, Jumo, Pringsurat, and Kandangan.

The main factors causing landslides in Kaloran Sub district is rainfall, slope, geology, soil movement vulnerability, and human activities.

1. Rainfall conditions in the Temanggung district, sub-district of Kaloran is high

2. The slope is at the criteria of a bit steep to steep. Slope conditions will change if there is a trigger factor. The main factor is triggered by rainy conditions so that the soil will contain moisture fragile high water, the next chunk of land does not bear the weight of authority that will move down and landslides.

3. According Thanden, et al. (1996), rock constituent in the disaster area is variation of clay stone, marl, tufaan sandstone, conglomerate, volcanic breccia and limes tones of Kerek Formation (TMK) and sandstone, breccia, tuff and clay stone lava flows from Penyatan Formation (QTP). This condition causes the rock like the fragile nature of the soil.

4. Based on Potential Forecast Land Movement Happened Map in Central Java (Geological Agency, Volcanology and Geological Hazard Mitigation Center), including the location of the ground motion in the region of the potential for ground movement which means the middle of this area has medium potential for the occurrence of ground motion if rainfall above normal, especially in the regions bordering the river valley, escarpment, the cliff path or if the slope impaired.

5. The act of the people of Kaloran Sub district, especially the exploitation of natural resources such as minerals for $\mathrm{C}$ Class, the traces of human of sand and stone mining in the Kledung Sub district have damaged the environment therefore caused landslides to be occured.

Based on these descriptions, the researcher aims to determine perceptions about landslides in Kaloran Sub district Temanggung, assessing landslide disaster management efforts by people in the Kaloran Sub district Temanggung, and knowing the landslide disaster management efforts by the government in the Kaloran Sub district Temanggung.

\section{Methods}

The research sample is an overall population of 37 households in three villages in the Kaloran Sub district that are in the Kalimanggis Village is 15 families, 17 families in Getas Village, and the Tleter Village is 5 families with the consideration that the three had high levels of vulnerability to landslides disaster marked almost every year in the three villages landslides occur mainly during the rainy season.

The variables in this study include: (1) Public perception of landslides studied based on three aspects, namely the perception of aspects of cognition, affective aspects, and aspects of conation. (2) Disaster landslides Prevention Variable in the study divided into two which are the landslide prevention by the society and prevention of landslides by the government (BPBD, sub districts, villages). Methods of data collection in this study using the test, questionnaire, interview, and observation. The analysis uses quantitative descriptive analysis and triangulation analysis.

\section{Results and Discussions}

\subsection{Results}




\subsubsection{Public Perception about Landslide Disaster (Cognition Aspects)}

The perception viewed from the aspects of cognition that knowledge plays an important role in people's life. Increased knowledge can improve the awareness and sensitivity about the knowledge of the public about the definition of landslides, causes, various phenomena of environmental degradation and disasters around the residence.

Based on Table 1 are known of 2 respondents $(5.40 \%)$ have the perception of the criteria is very less, they do not know the causes, common symptoms, the impact of landslides and their efforts to overcome. A total of 21 respondents $(56.76 \%)$ have less perception, most people already know the causes and effects of landslides, but do not know the common symptoms and the response to the disaster. A total of 11 respondents $(29.73 \%)$ have a good perception, respondents who are on these criteria have to know the causes, common symptoms and effects of landslides, but do not know how to overcome. A total of 3 respondents $(8.11 \%)$ have the criterion very good, they have to know the causes, common symptoms, effects, and management of landslides.

\subsubsection{Public Perception about Landslide Disaster (Affection Aspects)}

Perception viewed from the aspect of affection includes feeling and evaluation, both components play a role in people's life. Through the affective aspect, people can use reasoning to assess a good or bad thing and that can be done and what not to do. A person who has feelings and is able to evaluate will be encouraged to take precautions against environmental damage and disasters in his residence.

Based on Table 2 are known that 3 respondents $(8.11 \%)$ have very less perception, respondents who are on these criteria was frightened and traumatized by the landslide occurred, but they have not been able to evaluate the landslide mitigation action either by himself or by the government. A total of 7 respondents $(18.92 \%)$ have the perception that the criteria are less, they have been able to evaluate countermeasures by himself but have not been able to evaluate the response by the government. A total of 15 respondents $(40.54 \%)$ have a good perception, they have been able to evaluate mitigation actions by himself and partly government countermeasures. A total of 12 respondents $(32.43 \%)$ have a very good perception, they have been able to evaluate the landslide mitigation actions by themselves and by the government widely.

\subsubsection{Public Perception about Landslide Disaster (Conation Aspect)}

Conation aspect (attitude) is an important component for the realization of an action or behavior. The better a person's attitude in the facing the disaster phenomena, will be compelled to take action for the response to the disaster.

Based on Table 3 are known that 2 respondents $(5.40 \%)$ had the perception that is very less, they only know the response after the landslide occurred. A total of 6 respondents $(16.22 \%)$ have the perception that the criteria are less, because just knowing the response at stages during and after an avalanche course. A total of 17 respondents (45.95\%) had a good perception, they know the landslide disaster management efforts both stages before, during, and after the landslide occurred. A total of 12 respondents $(32.43 \%)$ have a very good perception of knowing landslide disaster management efforts both stages before, during, and after the landslide occurred in depth.

Table 1. Level of Public Knowledge About Landslide Disaster in Kaloran Sub district (Aspects of Cognition)

\begin{tabular}{ccccc}
\hline No & Percentage Interval Score & Criteria & Frequency & Percentage (\%) \\
\hline 1 & $0-7$ & Very Less & 2 & 5,40 \\
\hline 2 & $8-14$ & Less & 21 & 56,76 \\
\hline 3 & $15-21$ & Good & 11 & 29,73 \\
\hline 4 & $22-28$ & Very Good & 3 & 8,11 \\
\hline & & & 37 & 100 \\
\hline
\end{tabular}

Table 2. Public Perception about Landslide Disaster (Aspects of Affection)

\begin{tabular}{ccccc}
\hline No & Percentage Interval Score & Criteria & Frequency & Percentage (\%) \\
\hline 1 & $23-35$ & Very Less & 3 & 8,11 \\
\hline 2 & $36-50$ & Less & 7 & 18,92 \\
\hline 3 & $51-65$ & Good & 15 & 40,54 \\
\hline 4 & $66-80$ & Very Good & 12 & 32,43 \\
\hline & Number & 37 & 100 \\
\hline
\end{tabular}

Source: Primary Data, 2012 
Table 3. Public Perception About Landslide Disaster (Conation Aspect)

\begin{tabular}{ccccc}
\hline No & Interval Percentage Score & Criteria & Frequency & Percentage (\%) \\
\hline 1 & $16-28$ & Very Less & 2 & 5,40 \\
\hline 2 & $29-40$ & Less & 6 & 16,22 \\
\hline 3 & $41-52$ & Good & 17 & 45,95 \\
\hline 4 & $53-64$ & Very Good & 12 & 32,43 \\
\hline & Number & & 37 & 100 \\
\hline
\end{tabular}

Source: Primary Data, 2012

\subsection{Discussions}

\subsubsection{Public Perception about Landslide Disaster (Cognition Aspects)}

Based on the research results, it can be seen on the public perception of landslides which in this case is relatively less knowledge, ie 21 respondents $(56.76 \%)$. This is in accordance with a low educational background that the majority of the public elementary education. Majority of public knowledge is only in the category of sufficient because people just once follow the counseling of the landslide. This is in accordance with the results of the interview that in the Kaloran Sub district have once held counseling programs by Temanggung government handled by BPBD. The counseling is only followed by a small portion of society that most people's knowledge of landslides obtained only from their understanding of the phenomenon of landslides that occurred as well as through print and electronic media with limited information.

\subsubsection{Public Perception about Landslide Disaster (Aspects of Affection.)}

Based on the results of this research is that the public perception of landslides (affective aspects: feelings and evaluations) are classified as good, that is 15 respondents $(40.54 \%)$. This is because people often witnessed even become victims of landslides. Some people experience a landslide many times each year during the rainy season, giving rise to feelings of trauma / fear, feel materially harmed because there are parts of the house were destroyed by landslides. The intensity of landslides that often occur also provide experience for the community to evaluate how and what to do when a disaster both for prevention of landslides occur again.

\subsubsection{Public Perception about Landslide Disaster (Aspect of Conation)}

Based on the analysis of the survey results revealed that the public perception of landslides from Conation aspect quite good that is 17 respondents $(46 \%)$. Society has to know what efforts can be used to overcome the landslides, but sometimes people have not implement it because of constrained costs for the construction of the infrastructure for the creation and improvement of the cliff embankment back part of the house destroyed by landslides. Most people assume that the construction of a rock dike has an obligation to the land owner / neighbor.

\subsubsection{Landslide Disaster Management Efforts (Society)}

Landslides disaster management efforts by society are more likely to rescue and evacuation efforts. Mitigation efforts by the society is still lacking in the utilization of early warning because of limited funds and land constraints such as rainwater drains, dikes manufacture, and planting plants firmly rooted.

Landslide disaster management efforts by the community is still lacking in the use of early warning means and efforts that require funds or constrained by limited land as rain water drains, dikes manufacture, and planting plants firmly rooted.

On landslide prevention activities in the Kaloran Sub district BPBD not create and place signs warning of the dangers of landslides in the Kaloran Sub district, BPBD not supervise the implementation of regulations on spatial planning, building permits, BPBD Temanggung has yet to make a building structure that serves to prevent and reduce the impact of landslides due BPBD Temanggung is a newly formed entity that conducted the program is not maximized.

BPBD Temanggung has never relocate populations residing in areas prone to landslides in the district due regard Kaloran landslide that occurred in the Kaloran Sub district still relatively mild landslide that do not require relocation for residents who live in areas prone to landslides BPBD of Temanggung has never conduct business meeting basic needs (common kitchen) for victims of a landslide in the district due regard Kaloran landslide that occurred in the Kaloran Sub district a minor landslide did not cause many casualties Repair and reconstruction of infrastructure damaged by landslides executed BPBD Temanggung with funds obtained from state and local budgets of Temanggug government. BPBD collaborate with DKK to recover the social psychological conditions to eliminate the postdisaster trauma.

\section{Conclusions and Recommendations}

Based on the analysis, the results of research that has been done show public perception of landslides is based on aspects of cognition (knowledge) relatively less (56.76\%). Public perception of landslides based on aspects of affective 
(feeling and evaluation) are classified as good (40.54\%). Public perception of landslides from the aspects Conation (attitude) is quite good (45.95\%).

Landslide disaster management efforts by the Society is still lacking in the use of early warning means and efforts that require funds or constrained by limited land as rain water drains, dikes manufacture, and planting plants firmly rooted.

Landslide disaster management efforts by local governments (BPBD) is still lacking in terms of hazard warning signs, monitoring the implementation of regulations on spatial planning, building permits, relocation of residents who are in landslide-prone areas, satisfaction of basic needs and education of disaster.

Suggestions should be directed to the society to participate in disaster management efforts landslide. For Temanggung government should hold a landslide disaster response counseling on an ongoing basis. For the Government should provide a means of early warning of landslides are more sophisticated automated systems work.

\section{REFERENCES}

[1] Anonymous. General Guidelines for Community Based Disaster Management. IDEP Foundation. www. Idepfoundation.org / CBDM. (May 20, 2012).

[2] Astuti, Siti Irene and Sudaryono., 2010. Role of Schools in Disaster Mitigation Education. Journal of Disaster Management Dialog, Volume 11 Year 2010, p 30-42: State University of Yogyakarta.

[3] Hartuti, Evi Rine., 2009. Book Smart Earthquake. Yogyakarta: Diva Press.

[4] Temanggung Regency., 2009. Books Public Administration Report of Genesis. Temanggung Regency.

[5] Law of the Republic of Indonesia Number 24 Year 2007 on Disaster Management.

[6] Walgito, Bimo, 2003. Introduction to General Psychology. Yogyakarta: Andi Offset.

[7] Yani, Ahmad., 2010. Development and Simulation Training Center for Natural Disaster of National Disaster Education. GEA Journal, Volume 10 No. 1. Bandung: Indonesia University of Education. 